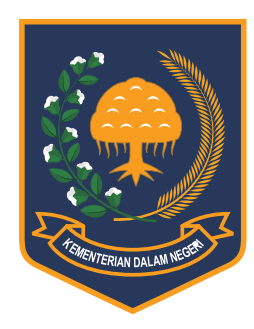

Jurnal Bina Praja 9 (1) (2017): 53-61

Jurnal Bina Praja

e-ISSN: 2503-3360 | p-ISSN: 2085-4323

Accreditation Number

735/AU2/P2MI-LIPI/04/2016

http://jurnal.kemendagri.go.id/index.php/jbp/index

\title{
Political Communication Strategy of the Regional Head In Managing Government in NorTh Gorontalo REgENCY
}

\author{
Yusa Djuyandi * \\ Department of Political Science \\ Universitas Padjadjaran \\ Jl. Raya Bandung - Sumedang, Jatinangor, Sumedang, Indonesia.
}

Received: 20 December 2016; Accepted: 8 April 2017; Published online: 31 May 2017

DOI: $10.21787 /$ jbp.09.2017.53-61

\begin{abstract}
Since elected as the Regent of North Gorontalo period of 2013-2018, various programs, especially with regards to improving the welfare of the people, have been done well by Indra Yasin so far. The success of development in North Gorontalo District is considered inseparable from the political communication capabilities undertaken by the regents in managing the government. Political communication strategy undertaken by Indra Yasin in managing government becomes important to analyze. This study used qualitative methods, in which the source of primary data obtained from interviews and observations, while secondary data obtained from the study of documentation and the Recent studies from literature. From the results of this research, the political communication strategies were undertaken by Indra Yasin in managing government were built through nurturing characters, strengthening political institutions, to promote unity and consensus building. The success in building a strategy of political communication, in the end, was able to bring the support from various elements of government, politics, and society to development programs that have been planned.
\end{abstract}

Keywords: The Regent, North Gorontalo, Political Communications, Local Government, Development.

\section{INTRODUCTION}

Since the Reform era, Indonesia's political system has undergone significant changes. For example, in Pilkada during the New Order period, the regional head was elected by the local parliament, but the election is now held directly by the people. Therefore, almost all political parties and candidates begin to use political approach through political communication. As in the election of Governor Gorontalo in 2011, the Rusli Habibie and Idris Rahim (RH-ID) couple were able to defeat Gusnar Ismail and Tony Uloly (GI-TU) couple. Though many parties predicted that GI-TU would win because, in addition to serving as the Governor and Deputy Governor, were also supported by the Democratic Party as the Government party.

Another part of the reality, Indra Yasin, formerly a deputy regent of Rusli Habibie (2008-2013) won the regent of Gorontalo Utara with his deputy Roni Imran for the period 2013-2018. Indra-Roni (sinar) victory was owned by comparison percentage of $51.37 \%$, the pair was supported by PKS, PAN, PPP, PDIP, Hanura, Demokrat, and Gerindra. The candidate number 1, namely Idrus Thomas MopiliRisjon Kudjiman Sunge (Bungkusjo), which is supported by Golkar, only ranks second with $24.20 \%$ vote, and candidate number 2 is an independent candidate, namely Thariq Modanggu-Hardi Hemeto (Taqdir), only managed to occupy third place with $24.43 \%$.

The key to the victory is claimed by the winning team as a tactical victory, and this research opens the realm of strategy from the political communication aspect of Indra Yasin (as the incumbent deputy) in winning the hearts of society and related institutions. Although Indra Yasin is known as the previous incumbent deputy, the political communication aspect, namely the care of the leader as the central figure, becomes a subject that cannot be underestimated. The maintaining aspect weighs more than developing.

The political communication strategy conducted by Indra Yasin in managing the

\footnotetext{
* Corresponding Author

Phone : +628179242566

Email : yusa.djuyandi@unpad.ac.id
} 
government becomes an important thing to be analyzed, which is how he should then be able to move the wheels of government in order to create good quality public services. In general, this is consistent with Thompson's view (2001) that describes the element of the leader's integrity as an important driver of the organization. Similarly, in North Gorontalo, the regional head figure becomes an important thing as the driving wheel of development in North Gorontalo. Through the communication it builds, the regional head can lower the vision and mission, develop appropriate planning to be submitted to his ranks as well as government partners.

A research on political communication strategy by the local head (Indra Yasin), especially in managing government in Kabupaten Gorontalo Utara, is something new. Other research on political communication strategy only raises the political communication strategy in the winning of candidate of regional head and president (Napitupulu, 2013; Narendra, 2012; Qalbi, 2015; Rosit, 2012) and political communication strategy by political party in campaign process (Al-Husainni \& Fuady, 2016; Herlambang, 2014; Pattiasina, 2015; Rachmiatie, Hasbiansyah, Khotimah, \& Ahmadi, 2013). From the previous research review, there is something that can be agreed, namely the right political communication strategy can be used to win the political competition in the election process, whether it is a presidential election, a legislative election, or a local election.

However, outside the context of the discussion on political communication strategies, there is another study of political communication by the head of the region. Among research from Fachrudin (2015) who assumes that political communication by the head of the region is considered able to maintain good relations with the community. As for Junaidi (2015), his study views that political communication conducted by the head of the region can be used as a tool to build support from the DPRD (local people representatives).

Associated with the research background and the formulated title, then the research needs to explain various concepts and theories related to political communication, especially related to political communication strategy. In addition, this study also explains the concept and theory of government as a form of explanation of the title. With the various concepts and theories presented, this research is expected to be more comprehensive, and thus able to analyze the phenomenon that occurs more deeply, through various perspectives of science, i.e. communication science and political science.

\section{A. Communication}

Basically, humans are social beings who need to interact with each other, therefore communication is important in human life as part of the interaction process itself. No exception for a regional head, in managing the government, a regional head needs to communicate, either vertically with his subordinates who are employees of the local government, or horizontally with his co-workers in the DPRD.

By communicating, humans can be interconnected with each other, either individually or in groups, in everyday life. The nature of communication is the process of statements between people (Effendy, 2003, p. 8). Communication, as proposed by Nimmo (2005, p. 6), is a process of social interaction that people use to construct meaning that is their image of the world (based on which they act) and to exchange that image through symbols.

Communication can also be interpreted as a form of human interaction that affects each other, intentionally or unintentionally. Not limited to forms of communication using verbal language, but also facial expressions, paintings, art, and technology (Cangara, 2012, p. 20). Communication occurs when there is a similarity of meaning about a message communicated by the communicator and accepted by the communicant (Effendy, 2003, p. 30). From it, can be interpreted that if there is no similarity of meaning between communicator and communicant, then the communication does not occur.

\section{B. Politics}

Politics is who gets what, when, and how; The division of values by the authorities; power and power holder; influence; actions directed towards maintaining and/or expanding other actions. From all these diverse views, there is a general conformity that politics includes something that people do; Politics is the process of activity (Nimmo, 2005, p. 8).

In general, it can be said that politics is a variety of activities in a political system (or country) that involves the process of determining that goal. It is a decision-making on whether the objectives of the political system concern the selection between several alternatives and the preparation of the priority scale of the chosen objectives.

To implement the policy, it is necessary to have power and authority, which will be used both to foster cooperation and to resolve conflicts that may arise in this process. The methods used can be persuasive and, if necessary, coercive. Without this constraint of wisdom, it is only a matter of mere desire (Ardial, 2010, pp. 23-24). Based on the opinions expressed above, it can be concluded that political understanding is a variety of activities in a political system that concerns the process of 
determining the objectives of the political system itself.

\section{Political Communication}

The term political communication is actually not a relatively new thing in the discipline of political science and communication science. Political communication according to (Cangara, 2014 , p. 16) is an interdisciplinary study built on various disciplinary fields, especially in relation to the process of communication and the political process. The term political communication began to be widely mentioned since the publication of (Almond \& Coleman, 1960), entitled The Politics of the Developing Areas. He discussed political communication in more detail. According to Almond (1960, pp. 12-17), the definition of political communication is one of the functions, which is always present in every political system, making it possible for political scientists to compare political systems with different cultural backgrounds.

Political communication is the process of delivering information about politics from government to society and from society to the government (Surbakti, 2010, p. 152). Meanwhile, Meadow in Cangara (2014, p. 35) defines political communications as follows: "Political communication refers to any exchange of symbols or messages that to a significant extent have been shaped by or have consequences for the political system." In here, Meadow emphasizes that symbols or messages conveyed are significantly shaped or have consequences for the political system.

According to Rush \& Althoff (2003, p. 24), political communication plays a very important role in the political system: this political communication determines the dynamic element and becomes a decisive part of political socialization, political participation, and political recruitment. The importance of the strategic role of political communication can also be seen from McNair's (2003) view of political communication, but the indicator of this view differs from that of Rush and Althoff, where McNair mentions "political communication as pure discussion about the allocation of public resources (revenues), Official authority (who is given the power to make legal, legislative, and executive decision), and official sanctions (what the state rewards or punishes). From what McNair has argued, it can be said that political communication is a process of discussion that speaks of the allocation of valuable public resources, the governmental authority given the power to make decisions both in the legislative and the executive, and the sanctions imposed by the government.

\section{Political Communication Strategy}

The nature of strategy in political communication is the overall conditional decision at this point about the action to be taken to achieve future political goals (Ardial, 2010, p. 73). Because in reality, the existence of political leaders is needed in every activity of political communication. After that, the right step for a political communicator to achieve political goals in the future, among others, is by treating the character that has been inherent in the political communicator and strengthens his political institutions.

According to Ardial (2010, p. 73) when political communications take place, it is not only political messages but especially who are political figures (politicians) or activists and professional leaders and from which institutions that convey the political message. In other words, the character of a political communicator and a political institution that supports it will determine the success or failure of political communication in achieving its goals and objectives. From that point, Ardial later determined to conclude that the political communication strategy is determined by several things, namely: the existence of political leaders, cohesiveness, and institutions, creating togetherness, negotiation, and building consensus.

Meanwhile, according to Arifin (2011, p. 235), a political communication strategy is the whole decision about the actions that will be executed today, in order to achieve future political goals, especially in terms of winning the election. Arifin further revealed that the political communication strategy, which according to him is considered appropriate for a political communicator, is through taking care of the character, establishing political institutions, creating togetherness, and building consensus.

Political communication strategy is a tactic that is so instrumental in winning elections. The success of a political communication strategy provides a major contribution to the use and planning of a candidate's or political party's pairs of strategies to draft not only in the face of elections but also postelection. The strategy is essentially planning and management to achieve a goal. However, to achieve these objectives, the strategy does not serve as a road map that shows the only direction but must be able to show how its operational tactics (Effendy, 2003).

\section{E. Government}

Governance has two meanings, namely in a broad sense and in a narrow sense. Governance in a broad sense called regarding or government, namely the execution of duties of all agencies, institutions, and officers who are entrusted with the authority to achieve the goals of the state. The meaning of 
government includes the legislative, executive, and judicial powers or other state apparatus that also act for and on behalf of the state. Meanwhile, the government in the narrow sense (bestuurvoering) includes the organization of functions that perform government duties. The emphasis of government in the narrow sense is only related to the power that conducts merely the executive functions (Sadjijono, 2008, p. 41).

The definition of government according to Riawan (2009, p. 197) is the governing body of a nation, state, city, etc., which is an institution or agency that organizes state or city governments and so on. Syafiie (2005, p. 20) is derived from the word government, in which at least the word "command" has four elements namely: there are two parties contained, the two parties are mutually related, the governing party has the authority, and the ruled party has the obedience.

Thus, based on the above definition, the government is an institution that has the power to do the job of ordering and organizing the government organization either from the central government to or local government in accordance with the government's affairs.

\section{MeThoD}

Research is done through observation and interview techniques. The data collected consist of primary data, which is from informant and observation, and secondary data in the field. For that, the design of this study uses qualitative methods. The research method is chosen and considered appropriate because the qualitative method is relevant and fits the research problem proposed through the interpretation of the process and meaning.

This data source is divided into two types of data sources, namely primary and secondary data sources. Primary data is data obtained directly through field observations and interviews with informants. Secondary data collected is through documentation study, in which the data is obtained through documentation relevant to this research.

The informants selected are observers in the field of political communication, the Regent of North Gorontalo, and the DPRD Chairman of North Gorontalo Regency While the secondary data sources in this study are various media sources used as a means of political communication in managing the government, the results of studies from various literature and previous studies that are relevant.

Testing the validity of the data in this study is based on certain criteria, namely the degree of data validity and truth obtained from the informants involved in the formation of political communication strategy and people who know about the political communication strategy of the Regent of Gorontalo
Utara. The truth of a description, conclusions, and explanations can be seen from the conformity with legislation and other important documents.

\section{RESULTS AND DISCUSSION}

In analyzing Indra Yasin's political communication strategy in managing governance in Kabupaten Gorontalo Utara, the researcher uses political communication strategy theory proposed by Arifin (2011, p. 235), where the right political communication strategy by communicator can be built through nurturing the character, establishing a political institution, creating togetherness, and building consensus.

\section{A. Nurturing the Character}

Success or failure in the implementation of political party communication function is closely related to the concepts that influence the function of political communication: the structure of political and economic culture (social system), the concept of party organization culture and management of political party communication strategy, credibility, capability, Figure or personality popularity (personality of the board) and the system of cadre, network, or party information access to the public and utilization of existing media (media system) as a channel of information or political messages to the public concerning demanding or public expectation, internal party conflict, and the interests of the elite, and the belief of the community/people towards the party, in this case the ideology of the party.

According to Arifin (2006: 54-55), several studies have shown voters' tendency in elections to make their choice to political heroes, which are candidates who fit their ideal image. The ideal position of the image is the politicians who have characters; because they have main characteristics such as skill, maturity, honesty, courage and so forth. It is the nature of political heroism. Thus, political heroes have their own charm, in the process of political communication to influence the audience, especially prospective voters. A political figure who is called a political hero is basically a formal or informal leader, who gets public or people trust.

According to an informant who is an observer and academician in the field of political communication from Gorontalo, Abdul Razak Mozin, "a positive image needs to be built using a strategy and maintained for a politician to remain sympathetic to the public, because if a politician has a bad image then the politician will be hard to be trusted by the public." The image of a politician must be a matter of serious concern. Politicians and leaders have an important role in a society whose expectations have a positive image so that people sympathize and give full confidence. 
In this aspect, Indra Yasin as an incumbent figure has advantages in terms of facilities and infrastructure of political capital. So, the possibility to gain strength in maintaining the image of his leadership so far will attract "sympathy" from parties who have brought it and other parties that may be interested in approaching it. Related to that, the observer of political communication Abdul Razak Mozin stated "Let's say that PKS, as the main supporting party, through a political speech by the chairman of DPD PKS elected 2015-2020, Gustam Ismail, stated that pragmatic and optimistic attitude will work together with any party that carries Indra Yasin in the upcoming 2018 election."

What is stated by Abdul Razak Mozin can also be seen from the statement of Gustam Ismail in his political oration when elected as Chairman of DPD PKS of North Gorontalo in 2015.

"We are preparing many qualified cadres, both for candidates of Regent and Vice Regent, opening the door to coalition with any party that has the same commitment to building this region with prosperity and justice" (Antara Gorontalo, 2015).

The subject is stated in order to strengthen the institutional candidates who are the incumbent and strengthening the party institution from the aspect of regeneration.

However, the optimistic attitude built between Indra Yasin and his supporting parties is certainly formed through positive perceptions of leadership figures, based on personal achievements and experiences or what is known either through mass media or online media. Information from various media lines that exist today certainly helps shape the image of Indra Yasin. A positive image is the main goal of a politician because it is impossible without a good image for a politician to get the trust of the people.

According to Ruslan (1994, p. 66), an image is abstract and can not be measured mathematically, but its form can be felt from the good or bad judgments assessed by the people. Imaging is certainly closely related in the political sphere because today's politicians are vying to display a positive image for people to have sympathy, provide support, and trust in them. For that reason, in building a positive image of Indra Yasin, of course, a well-crafted strategy is needed in order not to be mistaken in the process of interpreting a politician's self-image to the public.

Identity is one of the important factors that influence the success in forming a positive image because a good and strong identity is the main requirement to get a positive image (Ardial, 2010, p. 61). Political imagery is an image that requires a long process because it aims to form and activate each party's values as a solution to the life of the nation for the perception in the eyes of the public.
To build the image, in particular, the political image, takes time every day and not just every five years or when there will be elections.

According to an informant who is an observer of the field of political communications, most of the politicians interpret imaging as a closeness to journalists, for example, when all their comments about policy, achievements, and even criticism about Indra Yasin and his ranks are published in the mass media, such as www.antaragorontalo.com and other media, then that's imaging. Although the perception of imaging is synonymous with media coverage, political imagery by Indra Yasin is not only to build a discourse in the mass media but to mobilize the target audience by building their own awareness. From these statements, then the political imagery requires a process that is built with a mature strategy.

In political communication, especially political rhetoric or political speech in the presence of the masses, the essence of the audience will pay attention to whom (political figures) rather than to what (political messages) will be delivered. It means that the audience will be interested not to the content of the speech. This indicates that imaging is a very important thing in political communication. Thus, according to Arifin (2006: 55-57) , imaging in politics, which then gave birth to political heroism and charisma, can be obtained because of credibility, that is trustworthy because of the character and morality are praised in the relations among the society. Trust is also growing because of the expertise or abilities and skills in conveying the substance of the message he mastered. Expertise gained over a long time through formal or informal learning or education.

\section{B. Strengthening Political Institutions}

Nurturing or maintaining a persona as a major strategic step for political communication should be supported by a strategic move to raise the political institutions or strengthen the political institutions. This is very important because it is a fundamental factor in political communication, especially with regard to campaigning, imaging, and voting in elections.

Regarding institutional strengthening, the researcher, from the information of various informants, either from observers and academics, regional heads, and the chairman of the DPRD, sees that Indra Yasin conducts activities through the dualism of the function of political communication, where the institutional and the planting of a strong personal image support each other. Figure as a political communicator serves as a source of information on behalf of the institution, including the government institution he leads and the parties that carry him. This source of information runs in 
a line that is organized as a political weight or a meaning that depresses the society in following the course of government. In here, the political message plays a significant role, both written and unwritten, verbal and non-verbal, overt or hidden, even sometimes the political weight is not realized.

Arifin (2006: 61-63) states that the character of a politician, activist, or professional will increase if supported by a reputable institution or is part in the institution. So, the institution is a great force in helping the process of effective political communication. The institution is a forum of cooperation of several people to achieve common goals. In politics, the institution is a political party, parliament, and government or bureaucracy.

Non-political institutions, in essence, also have political power, although small and certainly not the same as political institutions. And talking about Institutional Strengthening from the context of Indra Yasin includes two main institutions, namely: the party as a bearer of strength and empowerment of the village as an institution.

The party, such as PKS as the main support party, in a committed manner, has proven consistent in support to the personality (Indra Yasin) who succeeds in making it a policy maker. The village, in the context of North Gorontalo, is specifically fostered and developed into a unit integrated with various aspects of Indra Yasin's policies. The concept of development that began proclaimed from 2015 "Strengthening Institutional and Village Apparatus" noted that the economic growth rate of the region with a population of 124,000 inhabitants increased to $7.12 \%$ with the poverty rate reached $18.11 \%$ or significantly decreased from the previous year of 2007 ranging from $33 \%$.

of course, the concept proclaimed by Indra Yasin has a fascination for some elements such as parties, villagers, and other stakeholders. Thus, in realizing it, Indra Yasin implements a method of political communication that integrates ideas, political power (parties and other elements), and potential that already exist in the region and society of North Gorontalo, so that the concept of development "Strengthening Institution and Village Apparatus" is not departing from empty dreams or simply unfounded and groundless ideas.

The consistent aspect of the party supports all sorts of the regent's wishes firmly enough. This is evident in his instructions to village units in North Gorontalo regarding the development of rice selfsufficiency. The assertiveness is reflected in Indra Yasin's statement:

"I instruct the community, especially farmers, to keep the rice fields in this area, do not convert the function, let alone be the location of office building and settlement and other functions. It will reduce the area of rice fields in this region," Saturday (24
September 2016) .

The effectiveness is proven by the harvesting of paddy field in Kwandang Sub-district which reaches 9 to 10 tons per hectare. Rice production in this area is quite good, from an average of 4.5 tons to 5.5 tons per hectare. In fact, farmers in the area of Bulalo Village, Kwandang Sub-district succeeded in increasing production to reach 10.5 tons per hectare (Source: katadata.co.id). In addition, Indra Yasin proposed alternative measures to support agriculture at the urban community level through the utilization of inactive land and home yard area as a productive agricultural location for food commodities such as sweet potatoes, vegetables, and spices.

Of course, the program is strengthened by the prohibition of the conversion of village rice field to other industrial buildings.

"If there is potential for the construction of office buildings and settlements and other public infrastructure, it is better to use inactive lands or not to convert the function of the rice fields."

The decision is not merely a political agenda, but quite solutive when Indra Yasin gave an alternative step to other business groups who intend to shift agricultural land. Although the current political promises, such as the wishes of the District Government through the existing budget allocation along with APBD funds to add new fields, are still in talks, but the development agenda becomes a common goal.

\section{Creating Togetherness}

In maintaining the harmony of cooperation between the figures and related institutions, then the goal of the next political communication strategy is to create togetherness between politicians and audiences (community). This is done by Indra Yasin by knowing the people and composing political messages in accordance with the conditions of the community. Arifin (2006: 63-64) states that:

"Homophily atmosphere that must be created between politicians and audiences is the equation of language (symbols of communication), the equation of fashion, the equation of 31 interests with the audience, especially about political messages, political methods, and media. But what is very important is which character will communicate to the audience".

That is, politicians or activists have had much in common with their audiences. The atmosphere is re-emphasized by Golkar practitioners (chairman of the North Gorontalo Parliament), Nurjanah Yusuf Mopili in his talks in the special plenary of North Gorontalo's Anniversary, attended by the governor and the deputy governor as well as the ranks of regents and members of parliament of North Gorontalo. Nurjanah acknowledged the 
achievements of regents and deputy regents who successfully transformed North Gorontalo into a mini-metropolitan city, with all its village-based uniqueness and agricultural industries.

Nurjanah also emphasizes the importance of cooperation of all parties, especially the elements of society, to remain active in supporting the change and development of North Gorontalo, through the fact:

"The society should not be a spectator in this area, they must continue to be optimistic and the experience and the history of the past must be used as a reference to build a prosperous region towards the religious community," (Antara Gorontalo, 2015).

Nurjanah's and Governor Rusli Habibie's optimistic attitude is reinforced by a better achievement of the macro-economic condition of North Gorontalo, as evidenced by the decrease of poverty rate from 33.33 percent in 2007 to $11.37 \%$ in 2014. In addition, the Economic growth of $7.75 \%$ and the unemployment rate of only $2.25 \%$ according to Gorontalo Provincial Government data in 2014 (source: BPS Gorontalo Utara, 2015) .

He also added that this good cooperation process will demand consensus between DPRD and the community as a unit as well as local government and other related agencies as other supporting units. For that reason, in the process, the next key aspect of the political communication strategy among these elements is to foster a strong consensus. This is because North Gorontalo as a blooming area with many 'homework' that are a shared responsibility.

\section{Building Consensus}

After the strategic stages of institutional strengthening and nurturing the character for mutual support in creating togetherness with the people through policy, then in order to maintain the stability of the order in the political infrastructure is by guarding the power in the consensus stage. The aspect of negotiation (lobbying) plays a very important role because the nature of political communication in this level becomes the main determinant in maintaining the integrity of power and policies that have been and will be taken.

There are two things to consider in building a consensus, among others, the first is the art of compromise, namely the politicians must have the ability to compromise, which is an art of its own. In general, the tip for the art or compromising is that it is a talent or innate and must be owned by a politician. Consensus or agreement is reached after a conflict or a difference of opinion on a problem (Arifin, 2003: 183) . This is also done by Indra Yasin in meetings, trials, or deliberations for the preparation of local regulations, the determination of programs, policies, and implementation. However, according to the Regent, in compromising there are boundaries that are then considered, among them the public interest as the main thing. So, if there is a political deal in policy formulation with the DPRD then the public interest is maintained.

The second, willing to open up. For politicians who will lobby to find solutions by building consensus must be ready to open themselves in accordance with the self-concept that exists in each politician who is differed in opinion (Arifin, 2003: 142) . In this context, the willingness to open oneself becomes what Indra Yasin holds as important, as this is also recognized by some political observers and the Chairman of the North Gorontalo DPRD, that a regent is a person who is able to accept all inputs to the development program he presents.

Self-concept is a very decisive factor in interactional political communication. Successful interactional communication, especially lobbying, depends on a lot of the quality of positive selfconcept. Politicians who have a positive self-concept are people who are transparent or open to others (Jorurard, 1971) .

Both of these are reflected in the meeting between the Governor and the Regent at the plenary session of the DPRD in commemoration of the 8th Anniversary of the Regency:

"The Regent and Deputy Regent of North Gorontalo, including other regional heads, in running the government should not break the joint venture and must run the programs and activities according to the Medium-Term Regional Plans (RPJMD),"

Although the Governors and Regents are promoted by different parties but there is awareness by the governor towards his subordinate on the potential of collaboration. The said cooperation is from the information that the researcher gets from the Regent and Chairman of the DPRD in which institutional strengthening can be built in building the community and its infrastructure. This integration is manifested in the same intent, consensus on the same development idea. Aligned in the effort desired by the regent and his staff, so the governor, within this framework, is given a position to support the aims.

This process can run due to the existence of one cohesion and alignment between the Governor Rusli Habibie, who was formerly Regent of North Gorontalo (2009-2011), with Indra Yasin, who was the deputy regent at that time. The commitment between the two of them in those years goes according to the expectations of the majority of the people so that the achievement makes it possible for Rusli Habibie to rise to governor.

With the strength of support, then it is a must for Indra Yasin, as the Regent, to not find any difficulty in running the wheels of government, and it is added to the pressure given by the Governor 
Rusli Habibie towards the ranks of the DPRD through his appeal:

"No more incidents will hamper the way of the regional government as it once did in North Gorontalo Regency which then was successfully mediated and resolved well," (Sako, 2015).

The stern critics are based on Rusli Habibie's absolute belief in the positive character possessed by Indra Yasin. Not only from the existing persona but also the confidence that has been awakened from international relations between both at once with the party and society.

\section{CONCLUSION}

As the Regent of North Gorontalo, Indra Yasin's political communication strategy is reflected clearly from the aspects of caring for characters, strengthening political institutions, creating togetherness, and building consensus. In caring for characters, Indra Yasin's personality in the eyes of society and supporting parties is certainly formed through a positive perception of his leadership figure. In the stabilizing aspect of political institutions, Indra Yasin conducts activities through the dualism of the function of political communication, where the institutional and the forming of strong personal image support each other. From the aspect of creating togetherness, the togetherness is built against politicians with the public (the community) by knowing the community and preparing political messages in accordance with the conditions. Meanwhile, from the last aspect, which is to build consensus, Indra Yasin is a regent and politician who is able to compromise and open up. From this can be concluded that the political communication strategy conducted by Indra Yasin in managing the government of North Gorontalo Regency can be done well.

\section{ACKNOWLEDGEMENT}

This research cannot be done without the help of many parties, therefore the researcher would like to express his gratitude to several parties who have helped the smoothness of this research, from the beginning to the end. Thanks to Mr. Abd. Razak Mozin who has helped in being the point of contact to several informants. Thanks also to informants who have taken the time to answer the questions in this study.

\section{REFERENCES}

Al-Husainni, Y. D., \& Fuady, M. . (2016). Strategi Komunikasi Politik Kader Muda Partai Gerindra 1 1,2. Prosiding Hubungan Masyarakat, 2(1), 257-265. Retrieved from http://karyailmiah.unisba.ac.id/index.php/humas/article/ view/2991
Almond, G. A., \& Coleman, J. S. (1960). The Politics of the Developing Areas. (G. A. Almond \& J. S. Coleman, Eds.). Princeton University Press.

Antara Gorontalo. (2015, April 26). HUT Ke-8 Gorontalo Utara, DPRD Apresiasi Pemkab. (H. Paat, Ed.), Antaragorontalo.com. Retrieved from http://www.antaragorontalo.com/berita/12953/hut-ke-8-gorontalo-utara-dprd-apresiasi-pemkab

Ardial. (2010). Komunikasi Politik. Jakarta: Indeks.

Arifin, A. (2011). Komunikasi Politik: Filsafat, Paradigma, Teori, Tujuan, Strategi, dan Komunikasi Politik Indonesia. Yogyakarta: Graha Ilmu.

Cangara, H. (2012). Pengantar Ilmu Komunikasi. Jakarta: PT Raja Grafindo Persada.

Cangara, H. (2014). Komunikasi Politik: Konsep, Teori, dan Strategi. Jakarta: Rajawali Pers.

Effendy, O. U. (2003). Ilmu Komunikasi: Teori dan Praktek (19th ed.). Bandung: Remaja Rosdakarya.

Fachrudin, T. (2015). Komunikasi Politik Kepala Daerah Berusia Muda (Studi Kasus Komunikasi Politik Bupati Tanah Bumbu Mardani H. Maming). Airlangga. Retrieved from http://repository.unair.ac.id/28743/

Herlambang, B. P. S. (2014). Strategi Komunikasi Politik Partai Gerindra (Studi Kasus Strategi Pemenangan Pemilu Legislatif Kota Malang 2014). Brawijaya.

Junaidi. (2015). Komunikasi Politik Kepala Daerah Hasil Pilkada Pengusungan Minoritas dalam Membangun Dukungan DPRD Kota Palangka Raya. Pencerah Publik, 2(1), 98-106. Retrieved from http://jurnal.umpalangkaraya.ac.id/ejur$\mathrm{nal} / \mathrm{pp} / \mathrm{pdf} / 243$

McNair, B. (2003). An Introduction to Political Communication. New York; London: Routledge.

Napitupulu, E. W. B. (2013). Strategi Komunikasi Politik dan Pemenangan Pemilu (Studi Kasus Strategi Komunikasi Politik Hulman Sitorus, SE dan Drs. Koni Ismail Siregar pada Masa Kampanye Pemilihan Umum Kepala Daerah Pematangsiantar 2010). Flow, 2(7), 1-9. Retrieved from http://jurnal.usu.ac.id/index. php/flow/article/view/11491

Narendra, R. A. (2012). Strategi Komunikasi Politik Pasangan Bambang-Icek dalam Pemilihan Umum Kepala Daerah Kabupaten Grobogan Tahun 2011. Politika: Jurnal Ilmu Politik, 3(1), 33-46. Retrieved from http://ejournal.undip. ac.id/index.php/politika/article/view/4827

Nimmo, D. (2005). Komunikasi Politik: Komunikator, Pesan, dan Media. Bandung: Remaja Rosdakarya.

Pattiasina, H. Y. (2015). Strategi Komunikasi Politik PDI Perjuangan Kabupaten Maluku Tengah pada Pemilu 2014. Jurnal Penelitian Komunikasi Dan Opini Publik, 19(1), 17-27. Retrieved 
from http://jurnal.kominfo.go.id/index.php/ jpkop/article/view/333

Qalbi, N. (2015). Strategi Komunikasi Politik dan Pemenangan Pasangan Muhammad Ramdhan Pomanto-Syamsu Rizal dalam Pemilihan Walikota dan Wakil Walikota Makassar Tahun 2013. Kritis: Jurnal Ilmu Sosial Dan Ilmu Politik, 1(2), 231-238. Retrieved from http://journal.unhas. ac.id/index.php/kritis/article/view/13

Rachmiatie, A., Hasbiansyah, 0., Khotimah, E., \& Ahmadi, D. (2013). Strategi Komunikasi Politik dan Budaya Transparansi Partai Politik. Mimbar: Jurnal Sosial Dan Pembangunan, 29(2), 123-132. Retrieved from http://ejournal.unisba.ac.id/index.php/mimbar/article/ view/384/300

Riawan. (2009). Hukum Pemerintahan Daerah. Bandung: Citra Aditya Bakti.

Rosit, M. (2012). Strategi Komunikasi Politik dalam Pilkada (Studi Kasus Pemenangan Pasngan Kandidat Ratu Atut dan Rano Karno pada Pilkada Banten 2011). Universitas Indone- sia. Retrieved from http://lib.ui.ac.id/detail?id=20301204\&lokasi=lokal\#horizontalTab1

Rush, M., \& Althoff, P. (2003). Pengantar Sosiologi Politik. Jakarta: Raja Grafindo Persada.

Ruslan, R. (1994). Praktik dan Solusi Public Relations dalam Situasi Krisis dan Pemulihan Citra. Jakarta: Ghalia Indonesia.

Sadjijono. (2008). Memahami Beberapa Bab Pokok Hukum Administrasi. Yogyakarta: Laksbang.

Sako, S. (2015, April 26). Gubernur Gorontalo Nasehati Bupati-Wabup Jangan Pecah Kongsi. (H. Paat, Ed.), Antaragorontalo.com. Retrieved from http://www.antaragorontalo.com/berita/12954/gubernur-gorontalo-nasehati-bupati-wabup-jangan-pecah-kongsi

Surbakti, R. (2010). Memahami Ilmu Politik. Jakarta: Gramedia Widiasarana.

Syafiie, I. K. (2005). Pengantar Ilmu Pemerintahan. Bandung: Refika Aditama.

Thompson, J. L. (2001). Understanding Corporate Strategy. London: Thomson Learning. 